\title{
Clinico-laboratory profile of Seropositive Celiac Diseases in Severe Acute Malnutrition
}

\author{
Meena P. ${ }^{1}$, Meena M. ${ }^{2}$, Khan N. ${ }^{3}$, Meena P. ${ }^{4}$ \\ ${ }^{1}$ Dr. Pradeep Meena, Professor, ${ }^{2}$ Dr. Mahendra Meena, Postgraduate Student, ${ }^{3}$ Dr. Namir Khan, Postgraduate Student, \\ ${ }^{4}$ Dr. Priyanka Meena, Postgraduate Student; all authors are attached with Department of Pediatrics, RNT Medical \\ College, Udaipur (Raj.) India.
}

Corresponding Author: Dr. Pradeep Meena, Professor, D-19, Doctor Quarters, MB Govt. Hospital Campus, Udaipur (Raj) India. E-mail: drpradeepmeena@ymail.com

\begin{abstract}
Introduction: Celiac Disease shares clinical features with malnutrition and may be responsible for malnutrition. The objective of this study was to study clinico-laboratory profile of seropositive Celiac Diseases in Severe Acute Malnutrition. Material \& Methods: The present study was a prospective, hospital based, observational study conducted at Malnutrition Treatment Centre (MTC) of tertiary care Pediatric hospital associated with government medical college of southern Rajasthan. The study was conducted over the period of one year from Dec. 2017 to Nov. 2018. Total 110 children with Severe Acute Malnutrition enrolled and screened for Celiac Disease on the basis of celiac serology (tTg$\mathrm{IgA} / \mathrm{IgG})$. Clinico-laboratory findings of celiac seropositive and seronegative patients were recorded and analysed statistically. Results: Celiacsero-positivity was observed in 30 cases (27.28\%). Out of these seropositive cases 14 cases $(46.66 \%)$ were seropositive for both $\mathrm{tTg}$-IgA and $\mathrm{IgG}$, while 9 cases $(30 \%)$ were positive for only $\mathrm{tTg}$-IgA and rest 7 cases $(23.33 \%)$ were positive for only tTg-IgG. Most of the seropositive patients $(12,40 \%)$ were in age group of $4-5$ years of age group. In seropositive cases recurrent blood in stool (54.45\%) and recurrent diarrhoea (52.94\%) were common clinical features at the time of admission. S. Vit. B12 \& Folic Acid were low in all the patients but more seropositive patients showed low levels of S. Folic acid ( $\mathrm{P}$ value $<0.05$ ). Conclusions: Recurrent diarrhoea and blood in stool were common presenting feature on admission in celiac seropositive patients suffering from severe acute malnutrition. Vit. B12 and Folic acid deficiency were also observed as a common finding in seropositive patients.
\end{abstract}

Keywords: Celiac Disease, Sero-positive, Severe Acute Malnutrition (SAM), Vit. B12.

\section{Introduction}

The word "Celiac" came from Greek word "Koilia", which means belly or abdomen. Celiac Disease is also known as celiac sprue, non-tropical sprue, gluten intolerance, gluten sensitive enteropathy [1].

Celiac Disease is a common cause of mal-absorption in the children and adults. It is characterized by an enteropathy and lifelong intolerance to gluten initiated by ingestion of gliadin related prolamines from cereals such as wheat, barley and rye in genetically susceptible individual [2]. The intolerance to gluten results in immune-mediated damage to the mucosa of the small intestine characteristically inducing villous atrophy and crypt hyperplasia that resolve with the removal of gluten from the diet [1].

Manuscript received: $14^{\text {th }}$ March 2019

Reviewed: $24^{\text {th }}$ March 2019

Author Corrected: $29^{\text {th }}$ March 2019

Accepted for Publication: $4^{\text {th }}$ April 2019
Although Celiac Disease is defined by the small intestine injury and resulting mal-absorption, more recently it has been recognized to be a multisystem disorder that may affect other organs, such as the bones, liver, skin, heart, genitals and nervous system [3-8].

The clinical presentation of Celiac Disease can vary from a classical mal-absorption syndrome to more subtle atypical gastrointestinal manifestations (similar to irritable bowel syndrome) or extra intestinal presentations (for example- infertility, malnutrition, osteoporosis, anemia, short stature, neurological \& psychiatric manifestations).

Celiac disease (CD) is one of the most common lifelong disorders in countries populated by individuals of European origin, affecting approximately $1 \%$ of the general population in worldwide [9]. 
Original Research Article

Exact incidence of disease in India is not known. CD is estimated to constitute $26 \%$ of all cases of malabsorption syndrome or $4-5 \%$ of all chronic diarrheas, In PGI, Chandigarh, 20-40 new patients are seen every year and $\mathrm{CD}$ constitutes $7 \%$ of indoor admissions and about $5 \%$ of the patients attending Pediatric Gastroenterology clinic [10].

Nutrition in Celiac Disease is an important issue. When someone who has Celiac Disease consumes food containing gluten, it reacts by attacking the intestinal villi.

Eventually, those tiny tentacles can be completely flattened, leaving them unable to do their job of absorbing nutrients. It doesn't matter how well a person eat if villi are destroyed by untreated celiac disease he is almost certain to be malnourished [11-13].

The clinical features of Severe Acute Malnutrition (SAM) often overlap with the common manifestations of Celiac Disease such as recurrent diarrhea, failure to thrive, vomiting, abdominal distension, anemia and weight loss [14-15]. As per NFHS-4 (2015-16) Severe Acute Malnutrition afflicts nearly $7.5 \%$ of children below 60 months of age in India [16].

Celiac disease could be major contributor or co-morbid condition in children with Severe Acute Malnutrition. This study was designed to evaluate the clinicolaboratory profile of seropositive Celiac Disease in children suffering from Severe Acute Malnutrition in $1-5$ years age group.

\section{Materials \& Methods}

The present study was single centric hospital based observational prospective study, conducted at Malnutrition Treatment Center (MTC) attached with tertiary care pediatric hospital associated with Government Medical College of Southern Rajasthan. The study was conducted during Dec. 2017 to Nov. 2018.

Study subject: All the children of 1-5 years age group suffering from Severe Acute Malnutrition (SAM) admitted in Malnutrition Treatment Centre.

\section{Inclusion Criteria}

1. All the children admitted with Severe Acute Malnutrition (meeting the WHO criteria for SAM) of age 1 to 5 years, exposed to gluten containing diet and

2. Parents willing for informed and written consent to enroll in the study

\section{Exclusion Criteria}

1. Seriously sick children with SAM admitted in PICU.

2. Patients with secondary malnutrition-known case of chronic medical or surgical disorders leading to malnutrition- Congenital Heart Diseases with CHF, Chronic renal failure, Hepatic Cholestas is, Thyrotoxicosis, Isolated Childhood Diabetes Mellitus, HIV, Childhood Tuberculosis, Cerebral Palsy, Genetic/ Chromosomal Syndromes, Inborn errors of Metabolism (IEM), Malignancies, Surgical resection of intestine etc.

3. Patients with known celiac serology.

Intervention: Prior approval for ethical clearance was sought from Institutional Ethical Committee. After obtaining informed written consent from both the parents, patients were enrolled for the study.

Detailed clinical and dietary history followed by anthropometric measurements and examination was done.

Blood sample was collected for relevant investigations. Celiac serology was accessed by screening for tissue trans- glutaminase IgA/IgG by ELISA method (Aeskulisat $\mathrm{tTg}-\mathrm{IgA} / \mathrm{tTG}-\mathrm{IgG}$ new generation antigen based kit by Aesku. Diagnostics. Gmbh \& Co. Kg). As per manufacturer manual of the kit cut off value for seropositivity for $\mathrm{tTg}-\mathrm{Ig} \mathrm{A} / \mathrm{IgG}$ was $>18 \mathrm{U} / \mathrm{ml}$ (As per manufacturer manual of the kit -normal range for tTgIgA \& tTg-IgG: 12-18 unit/ml) [17].

All the collected data were managed and analyzed with standard software (SPSS Version 20). P-value of $<0.05$ was considered significant.

\section{Results}

Total 110 children with Severe Acute Malnutrition in age group 1-5 years, admitted in MTC were enrolled and screened for celiac serology. Out of these 110 cases celiac serology was positive in 30 cases with sero-positivity of $27.28 \%$. 
Table No-1: Sero-positivity pattern according to $\mathrm{tTg}-\mathrm{IgA} / \mathrm{IgG}$

\begin{tabular}{|c|c|c|}
\hline Sero-positivity* & No. & (\%) \\
\hline Only tTg-IgA Positive & 9 & $30 \%$ \\
\hline Only tTg-IgG Positive & 7 & $23.33 \%$ \\
\hline Both tTg-IgG \&IgA Positive & 14 & $46.66 \%$ \\
\hline Total Seropositive & $\mathbf{3 0}$ & $100 \%$ \\
\hline
\end{tabular}

*Cut-off values: $\mathrm{tTg}-\mathrm{IgA} / \mathrm{tTg}-\mathrm{IgG}=>18 \mathrm{U} / \mathrm{ml}$ (As per manufacturer manual for the kit) [17].

Out of total 30 seropositive cases, 14 (46.66\%) cases were seropositive for both tTg-IgA and IgG, while only tTg-IgA and only tTg-IgG were positive in 9 (30\%) and 7 (23.33\%) cases, respectively (Table-1).

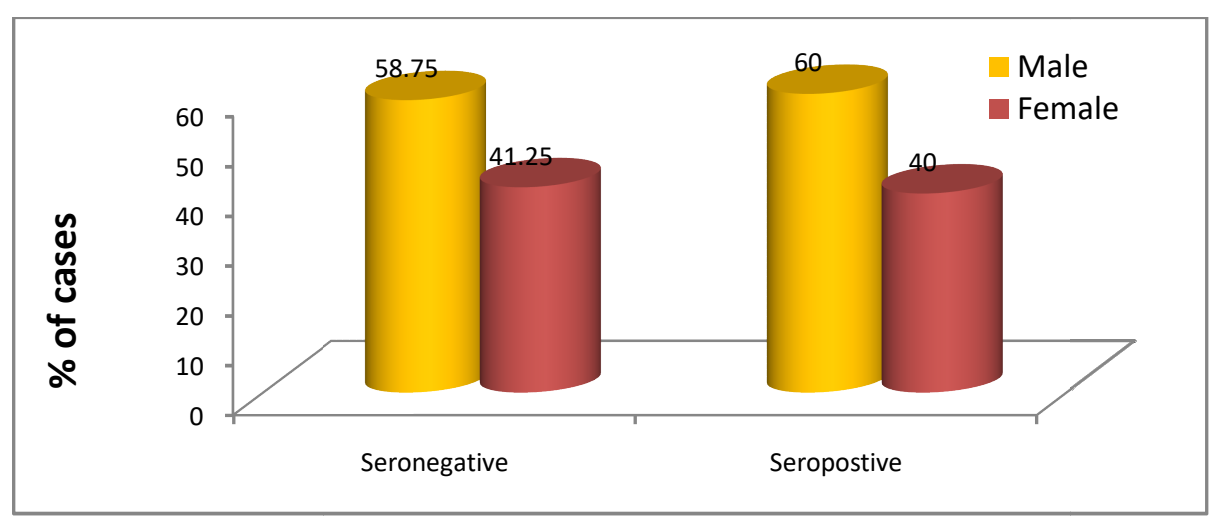

Figure-1: Gender wise distribution of Sero-positivity

Celiac Disease sero-positivity was more in males $(60 \%, 18$ in 30$)$ as compared to females $(40 \%, 12$ in 30$)$, and this difference in sero-positivity was statistically insignificant (P-value $>0.05)$ (Figure-1)

Table No-2: Distribution of Seropositivity According to Age group.

\begin{tabular}{|c|c|c|c|c|c|c|c|c|c|c|}
\hline \multirow{3}{*}{$\begin{array}{c}\text { Age } \\
\text { group } \\
\text { (yrs) }\end{array}$} & \multirow{2}{*}{\multicolumn{2}{|c|}{$\begin{array}{l}\text { Seronegative } \\
\qquad(\mathbf{n}=\mathbf{8 0})\end{array}$}} & \multicolumn{8}{|c|}{ Seropostive $(n=30)$} \\
\hline & & & \multicolumn{2}{|c|}{$\begin{array}{c}\text { Only tTg IgA } \\
\text { Positive }\end{array}$} & \multicolumn{2}{|c|}{$\begin{array}{l}\text { Only tTg IgG } \\
\text { Positive }\end{array}$} & \multicolumn{2}{|c|}{$\begin{array}{l}\text { tTg IgA + IgG } \\
\text { both Positive }\end{array}$} & \multicolumn{2}{|c|}{ Total } \\
\hline & No. & $\%$ & No & $\%$ & No. & $\%$ & No. & $\%$ & No & $\%$ \\
\hline $1-2$ & 49 & 61.25 & 4 & 44.44 & 3 & 42.86 & 2 & 14.29 & 9 & 30 \\
\hline $2-3$ & 15 & 18.75 & 1 & 11.11 & 1 & 14.29 & 4 & 28.57 & 6 & 20 \\
\hline $3-4$ & 5 & 6.25 & 1 & 11.11 & 1 & 14.29 & 1 & 7.14 & 3 & 10 \\
\hline $4-5$ & 11 & 13.75 & 3 & 33.33 & 2 & 28.57 & 7 & 50 & 12 & 40 \\
\hline Total & 80 & 100 & 9 & 100 & 7 & 100 & 14 & 100 & 30 & 100 \\
\hline
\end{tabular}

Seropositivity of only Serum tTg IgA and only tTg IgG was maximum (4/9, 44.44\%; 3/7, 42.86\%) in age group 1-2 years while sero-positivity of both tTg-IgA and IgG was maximum (7/14, 50\%) in age group 4-5 years (Table -2).

Table-3: Mean Age and anthropometric measurements in cases

\begin{tabular}{|c|c|c|c|c|c|}
\hline \multirow{2}{*}{ Parameters } & \multicolumn{2}{|c|}{ Seronegative } & \multicolumn{2}{c|}{ Peropositive } & \multirow{2}{*}{ S-Value } \\
\cline { 2 - 5 } & Mean & SD & Mean & $\mathbf{0 . 0 2}$ \\
\hline Age (yrs) & 1.69 & \pm 1.24 & 2.65 & \pm 1.54 & $\mathbf{0 . 0 4}$ \\
\hline \multicolumn{7}{|c|}{ Anthropometric Measurements } \\
\hline Weight $(\mathrm{Kg})$ & 6.81 & \pm 1.88 & 7.24 & \pm 2.24 & $\mathbf{0 . 0 1}$ \\
\hline Height $(\mathrm{cm})$ & 74.95 & \pm 10.20 & 81.23 & \pm 12.49 & 0.54 \\
\hline MUAC $(\mathrm{cm})$ & 11.10 & \pm 1.41 & 11.26 & \pm 1.17 & \\
\hline
\end{tabular}




\section{Original Research Article}

The mean age, mean weight and mean height in seronegative $\mathrm{v} / \mathrm{s}$ seropositive was $1.69 \pm 1.24 \mathrm{v} / \mathrm{s} 2.65 \pm 1.54,6.81 \pm 1.88 \mathrm{v} / \mathrm{s}$ $7.24 \pm 2.24$ and $74.95 \pm 10.20 \mathrm{v} / \mathrm{s} 81.23 \pm 12.49$. The difference among the all three parameters was statistical significant $(\mathrm{P}-$ value $<0.5)$. While mean MUAC was $11.10 \pm 1.41 \mathrm{v} / \mathrm{s} 11.26 \pm 1.17$. The difference in MUAC in seronegative and seropositive cases was statistically insignificant (p-value $>0.5)$ (Table-3).

Table No-4: Weight/Height Z-score in cases

\begin{tabular}{|c|c|c|c|c|}
\hline \multirow{2}{*}{ Weight/ Height } & \multicolumn{2}{|c|}{ Seronegative } & \multicolumn{2}{c|}{ Seropositive } \\
\cline { 2 - 5 } & No. & $\mathbf{\%}$ & No. & \% \\
\hline$<-2$ SD & 4 & 5 & 0 & 0 \\
\hline$<-3$ SD & 76 & 95 & 30 & 100 \\
\hline Total & $\mathbf{8 0}$ & $\mathbf{1 0 0}$ & $\mathbf{3 0}$ & $\mathbf{1 0 0}$ \\
\hline
\end{tabular}

Total no. of cases in form of Z-score $(<-2 \mathrm{SD},<-3 \mathrm{SD})$ in seronegative group and seropositive group were 4,76 and 0,30 respectively. This difference in sero-negative and sero-positivecases was statistically insignificant $(\mathrm{P}-\mathrm{value}=>0.05)$ (Table-4).

Table No- 5: Mean Age of Gluten Sensitization in Seropositive and Seronegative Cases

\begin{tabular}{|c|c|c|c|c|c|}
\hline \multirow{2}{*}{ Age group (Months) } & \multicolumn{2}{|c|}{ Sero-negativity } & \multicolumn{2}{c|}{ Sero-positivity } & \multirow{2}{*}{ P value } \\
\cline { 2 - 5 } & No. & $\mathbf{\%}$ & No & \% & \\
\hline$<6$ & 10 & 76.92 & 3 & 23.08 & 26.74 \\
\hline $6-12$ & 63 & 73.26 & 23 & 36.36 & \\
\hline $12-18$ & 7 & 63.64 & 4 & $>0.05$ \\
\hline $\begin{array}{c}\text { Mean Age (Months) of starting } \\
\text { Gluten containing diet }\end{array}$ & \multicolumn{2}{|c|}{$8.47 \pm 2.98$} & $8.35 \pm 2.15$ & \multirow{2}{*}{} \\
\hline
\end{tabular}

The mean age of starting gluten containing diet in seronegative and seropositive group was $8.47( \pm 2.98)$ and $8.35( \pm 2.15)$ respectively. This difference was statistically insignificant $(\mathrm{P}$-value $>0.05)$ (Table-5).

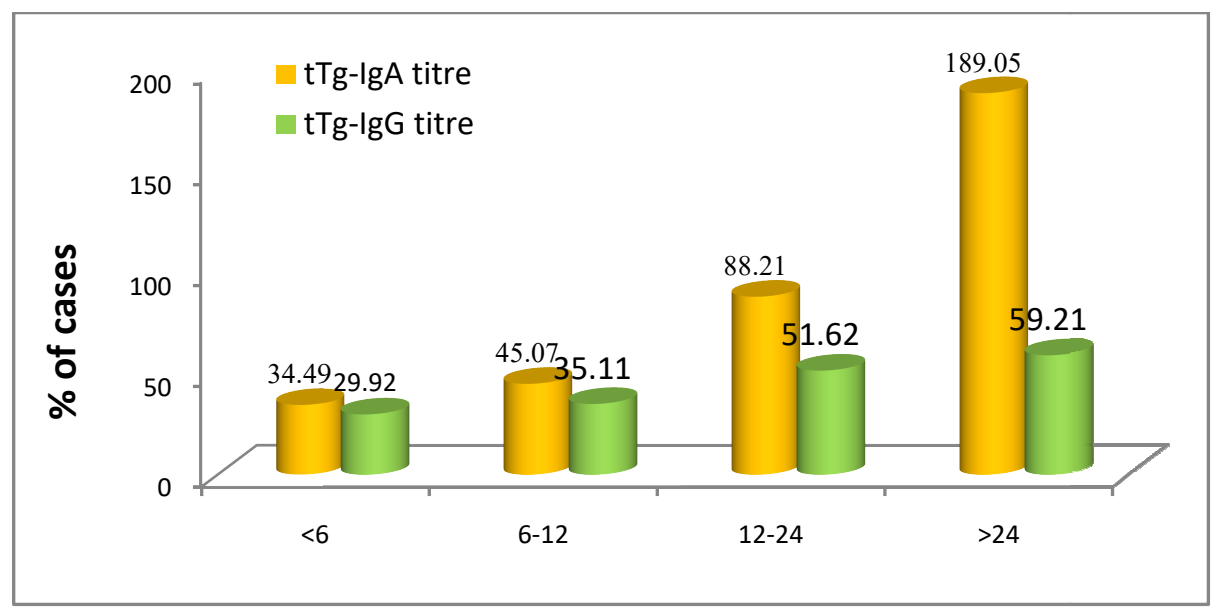

Figure-2: Mean tTg sero-titre according to duration of gluten containing diet ingestion

The mean sero-titre of $\mathrm{tTg}-\operatorname{IgA}$ and IgG increases with the duration of gluten containing diet consumption (Figure-2). Irritability (80\%) and anorexia (76.47\%) were common clinical features in seronegative cases while in seropositive cases recurrent blood in stool $(54.45 \%)$ and recurrent diarrhoea $(52.94 \%)$ were common clinical features at the time of admission ( $\mathrm{P}$ value $<0.05)$. In only $\mathrm{tTg}-\mathrm{IgA}$ seropositive cases common clinical feature was recurrent diarrhea $(17.65 \%)$ while in tTg-IgG seropositive cases recurrent blood in stool $(21.43 \%)$ was common (P value $<0.05)($ Table-6).

In seropositive cases chelosis of tongue was common sign (50\%) followed by nail changes (30.76\%) and pallor (27.05\%) but there was no statistically significant difference $(\mathrm{P}$ value $>0.05)$ among the clinical signs between seropositive and seronegative groups (Table-6). 
Original Research Article

Table No.-6: Distribution of Clinical Sign \& Symptoms According Seropositivity

\begin{tabular}{|c|c|c|c|c|c|c|c|c|c|c|c|c|}
\hline \multirow{3}{*}{$\begin{array}{l}\text { Clinical } \\
\text { Features }\end{array}$} & \multirow{2}{*}{\multicolumn{2}{|c|}{$\begin{array}{l}\text { Seronegative } \\
\quad(\mathbf{n}=\mathbf{8 0})\end{array}$}} & \multicolumn{8}{|c|}{ Seropositive $(n=30)$} & \multirow{3}{*}{ Total } & \multirow{3}{*}{$\begin{array}{c}P \\
\text { value }\end{array}$} \\
\hline & & & \multicolumn{2}{|c|}{$\begin{array}{c}\text { Only tTg IgA } \\
\text { Positive } \\
(n=9)\end{array}$} & \multicolumn{2}{|c|}{$\begin{array}{c}\text { Only tTg } \\
\text { IgG Positive } \\
(n=7)\end{array}$} & \multicolumn{2}{|c|}{$\begin{array}{c}\text { Both tTg IgA } \\
\text { \& IgG Positive } \\
(n=14)\end{array}$} & \multicolumn{2}{|c|}{ Total } & & \\
\hline & No. & $\%$ & No. & $\%$ & No. & $\%$ & No. & $\%$ & No. & $\%$ & & \\
\hline $\begin{array}{c}\text { Rec. } \\
\text { Diarrhea }\end{array}$ & 24 & 47.06 & 9 & 17.65 & 5 & 9.80 & 13 & 25.49 & 27 & 52.94 & 51 & $<0.001$ \\
\hline $\begin{array}{l}\text { Rec. Blood } \\
\text { in stool }\end{array}$ & 5 & 45.45 & 0 & 0.00 & 3 & 21.43 & 3 & 21.43 & 6 & 54.45 & 11 & $<0.03$ \\
\hline $\begin{array}{c}\text { Rec. } \\
\text { Vomiting }\end{array}$ & 21 & 61.76 & 2 & 5.88 & 3 & 8.82 & 8 & 23.53 & 13 & 38.23 & 34 & 0.10 \\
\hline $\begin{array}{l}\text { Rec. Abd. } \\
\text { Pain }\end{array}$ & 19 & 61.29 & 3 & 9.68 & 2 & 6.45 & 7 & 22.58 & 12 & 38.70 & 31 & 0.24 \\
\hline $\begin{array}{c}\text { Abd. } \\
\text { Distension }\end{array}$ & 35 & 66.04 & 3 & 5.66 & 4 & 7.55 & 11 & 20.75 & 18 & 33.96 & 53 & 0.07 \\
\hline Anorexia & 26 & 76.47 & 2 & 5.88 & 3 & 8.82 & 3 & 8.82 & 8 & 36.00 & 34 & 0.69 \\
\hline Wt. loss & 16 & 64.00 & 2 & 8.00 & 2 & 8.00 & 5 & 20.00 & 9 & 36.00 & 25 & 0.61 \\
\hline Irritability & 28 & 80.00 & 3 & 8.57 & 2 & 5.71 & 2 & 5.71 & 7 & 20.00 & 35 & 0.49 \\
\hline \multicolumn{13}{|c|}{ Clinical Sign } \\
\hline Pallor & 62 & 72.94 & 5 & 5.88 & 6 & 7.06 & 12 & 14.12 & 23 & 27.05 & 85 & 0.35 \\
\hline Oedema & 10 & 76.92 & 1 & 7.69 & 1 & 7.69 & 1 & 7.69 & 3 & 23.0 & 13 & 0.95 \\
\hline Skin change & 18 & 78.26 & 3 & 13.04 & 1 & 4.35 & 1 & 4.35 & 5 & 21.73 & 23 & 0.43 \\
\hline $\begin{array}{l}\text { Nails } \\
\text { change }\end{array}$ & 8 & 61.54 & 1 & 7.69 & 1 & 7.69 & 2 & 15.38 & 4 & 30.76 & 12 & 0.96 \\
\hline $\begin{array}{c}\text { Tongue } \\
\text { Chelosis }\end{array}$ & 1 & 50.00 & 1 & 50.00 & 0 & 0.00 & 0 & 0.00 & 1 & 50 & 2 & 0.18 \\
\hline $\begin{array}{l}\text { Hairs hypo- } \\
\text { pig. }\end{array}$ & 48 & 73.85 & 4 & 6.15 & 4 & 6.15 & 9 & 13.85 & 17 & 26.15 & 65 & 0.81 \\
\hline
\end{tabular}

TableNo-7: Hematological profile in cases

\begin{tabular}{|c|c|c|c|c|c|}
\hline \multirow{2}{*}{$\begin{array}{l}\text { Hematological } \\
\text { indices }\end{array}$} & \multicolumn{2}{|c|}{$\begin{array}{l}\text { Seronegative } \\
\quad(n=80)\end{array}$} & \multicolumn{2}{|c|}{$\begin{array}{c}\text { Seropositive } \\
(\mathrm{n}=\mathbf{3 0})\end{array}$} & \multirow[t]{2}{*}{$P$ value } \\
\hline & Mean & SD & Mean & SD & \\
\hline $\mathrm{Hb}$ & 7.81 & \pm 2.45 & 8.21 & \pm 2.58 & 0.464 \\
\hline Hct & 26.12 & \pm 7.64 & 26.16 & \pm 8.12 & 0.981 \\
\hline $\mathrm{MCV}$ & 69.47 & \pm 15.14 & 71.48 & \pm 15.04 & 0.284 \\
\hline $\mathrm{MCH}$ & 23.55 & \pm 17.35 & 23.66 & \pm 6.27 & 0.142 \\
\hline $\mathrm{MCHC}$ & 29.71 & \pm 4.08 & 30.91 & \pm 3.18 & 0.589 \\
\hline TLC & 11911.99 & \pm 7235.11 & 10810.77 & \pm 7550.19 & 0.492 \\
\hline
\end{tabular}

In Seronegative v/s Seropositive cases mean haemoglobin $(7.81 \pm 2.45 \mathrm{v} / \mathrm{s} 8.21 \pm 2.58 \mathrm{gm} \%)$, mean Hct $(26.12 \pm 7.64 \mathrm{v} / \mathrm{s}$ $26.16 \pm 8.12 \%)$, mean MCV $(69.47 \pm 15.14 \mathrm{v} / \mathrm{s} 71.48 \pm 15.04 \mathrm{fl})$, mean MCH $(23.55 \pm 17.35 \mathrm{v} / \mathrm{s} 23.66 \pm 6.27 \mathrm{pg})$, mean MCHC $(29.17 \pm 4.08 \mathrm{v} / \mathrm{s} 30.91 \pm 3.18 \mathrm{~g} / \mathrm{dl})$ were lower in Seronegative group. while mean TLC (11911.99 \pm 7235 $\mathrm{v} / \mathrm{s} .110810 .77 \pm 7550.19$ cells $/ \mathrm{mm}^{3}$ ) were lower in seropositive cases but there was no statistical significant (P-value $>0.05$ ) (Table -7).

In seropositive cases folic acid deficiency was present in 30\% (9 out of 30) children while in seronegative cases it was present in $6.25 \%$ (5out of 80 ) children. The difference observed in folic acid deficiency between seropositive and seronegative cases was statistically significant $(\mathrm{P}$ value $<0.05)$ (Figure-3). 
Original Research Article

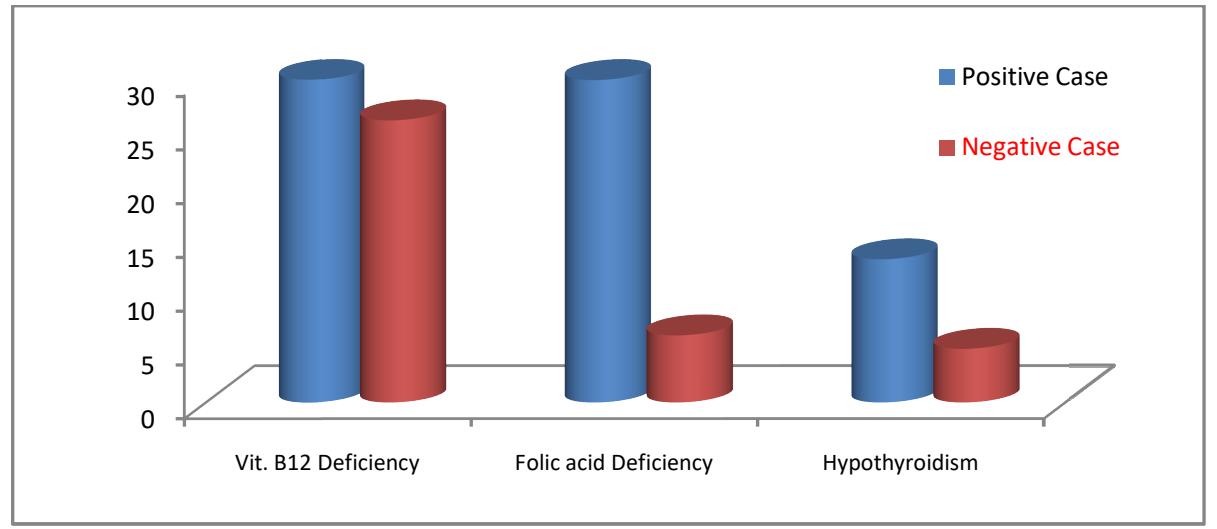

Figure-3: Vit.-B12, Folic Acid levels and Thyroid status in cases

*Vitamin B-12 Deficiency $<200 \mathrm{pg} / \mathrm{dl}^{19} *$ Folic acid deficiency $<3 \mathrm{ng} / \mathrm{dl}^{20}$ (*TSH:-Normal value:-0.5- 4.5 $\mu \mathrm{IU} / \mathrm{ml}$, and subclinical hypothyroidism: TSH $>4.5$ With $\mathrm{T}_{3}, \mathrm{~T}_{4}$ Normal) [21].

Microcytic hypochromic anemia was more common finding in seronegative cases (66.25\%) than seropositive cases $(50 \%)$, while normocytic normochromic more common in seropositive cases but the difference between two groups was statistically not significant (PValue $>0.05$ ) (Figure-4).

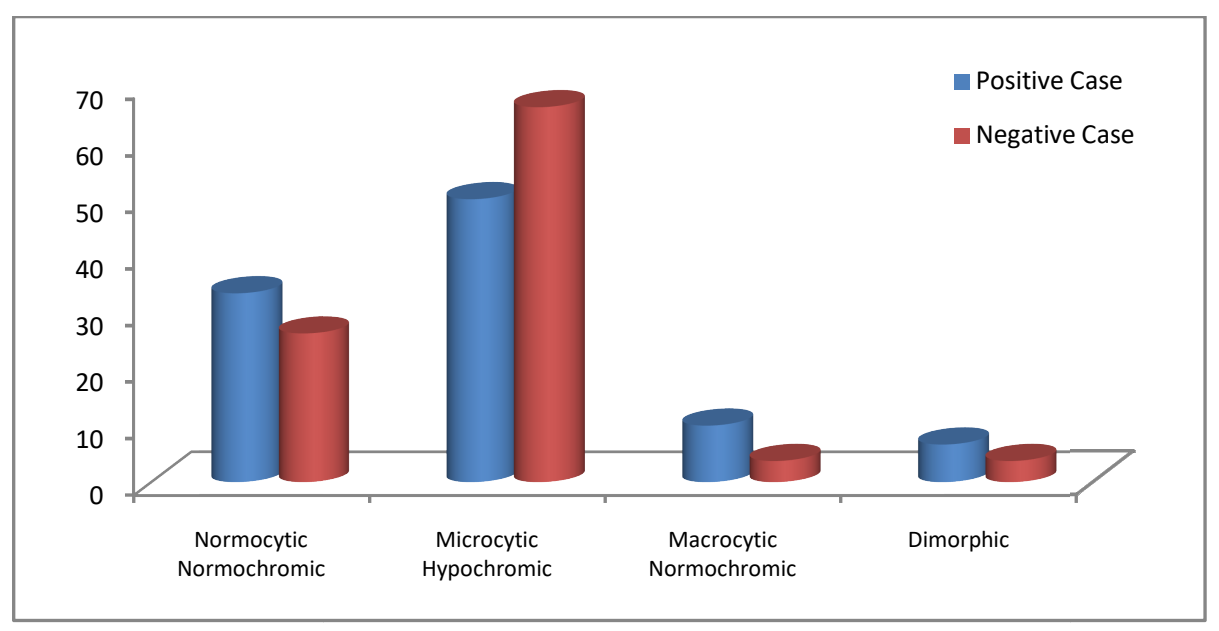

Figure-4: PBF-type of anemia in cases

\section{Discussion}

Celiac Disease is a common disorder in children with variable presentation. Clinical manifestation of Celiac Disease and Severe Acute Malnutrition (SAM) in children overlap each other. Celiac Disease may be underlying cause responsible for Malnutrition in these children. Purpose of this study was to evaluate the clinico-laboratory profile of seropositive Celiac Disease in children of 1 to 5 years age suffering from Severe Acute Malnutrition.

Overallsero-prevalence of Celiac Disease in our study among the children suffering from severe acute malnutrition was $27.28 \%$ (30 out of 110 ). Out of these seropositive cases 7 patients (23.33\%) showed only tTg-IgG positive serology and these patients may have underlying IgA deficiency and may be missed if accessed for $\mathrm{tTg}$-IgA only.
Prevalence reported by Kumar P et al was $13.1 \%$ (seropositive and biopsy confirmed) among the SAM children [14]. Sero-prevalence for Celiac Disease reported by Beniwal $\mathrm{N}$ et al was $15.38 \%$ while prevalence of biopsy confirmed Celiac disease was $14.42 \%$ among the SAM children [15]. We compared various parameters in Celiac Disease seronegative and seropositive cases. Sero-positivity was more in males as compared to females. Similarly male preponderance in sero-positivity was reported by Kumar Pet al [14] and Sharma M et al [18]. This suggests gender biasness in society as more male children brought for admission as compared to females.

Celiac Disease sero-positivity was maximum in 4-5 years age groups, suggesting cumulative effect of gluten in ingested diet with the age. 


\section{Original Research Article}

Anthropometric measurements were comparable in sero-nergative and sero-positive cases without statistical significant difference. Anthropometric measurements were consistent with Severe Acute Malnutrition. There was no significant difference in mean age of starting gluten containing diet in sero-negative and sero-positive cases. The mean age of starting gluten containing diet in seropositive cases was $8.35 \pm 2.15$ months. Beniwal $\mathrm{N}$ et al [15] reported mean age of starting gluten containing diet in Celiac Disease children of $10.33 \pm 5.20$ months.

In our study mean age of starting gluten containing diet in sero-positive cases was less because most of the enrolled cases were between 1-2 years of age. We also observed that mean titre of $\mathrm{tTg}-\operatorname{IgA}$ and $\mathrm{IgG}$ increased with duration of gluten containing diet consumption which is suggestive of cumulative effect of gluten with duration of gluten ingestion.

We observed that recurrent diarrhea was more common clinical features at the time of admission in seropositive cases in comparison to seronegative cases ( $\mathrm{P}$ value $<0.001)$. In only $\mathrm{tTg}-\operatorname{IgA}$ sero-positive cases common clinical feature was recurrent diarrhea while in tTg-IgG sero-positive cases recurrent blood in stool was common clinical feature. Only $\mathrm{tTg}$-IgG seropositive cases may have underlying $\operatorname{IgA}$ deficiency leading to recurrent invasive GI infection causing recurrent blood in stool.

In these patients serum $\operatorname{IgA}$ estimation needed to rule out IgA deficiency. Kumar P et al [14] and Beniwal N et al [15] reported chronic diarrhea as a common clinical feature of Celiac Disease in children suffering from Severe Acute Malnutrition.

We observed that in sero-positive cases chelosis of tongue was common $(50 \%)$ clinical sign followed by nail changes $(30.76 \%)$, pallor $(27.05 \%)$, hair hypopigmentation $(26.15 \%)$ and skin change $(21.72 \%)$, but there was no statistical significant difference (P-value $>0.05$ ) among the clinical signs between sero-positive and sero-negative cases. All the clinical signs were consistent with signs of Severe Acute Malnutrition.

We analyzed hematological parameters $(\mathrm{Hb}, \mathrm{Hct}, \mathrm{MCV}$, $\mathrm{MCH}, \mathrm{MCHC}$ ) and observed that the microcytic hypochromic anemia was common in all the malnourished children.

In this study we assessed for Vit.-B12 and Folic Acid deficiency status by estimation of S.Vit.-B12 and Folic acid levels. Both seropositive and seronegative cases were Vit-B12 and Folic acid deficient (S. Vit.-B12 levels $<200 \mathrm{pg} / \mathrm{dl}$ and Folic Acid <3ng/dl) but difference of Vit.
B-12 in between two groups was statistically insignificant but difference of Folic Acid deficiency was statistically significant (P-value $<0.05$ ) between two groups. Macrocytic anemia in PBF was found in $10 \%$ of seropositive cases and only in $3.75 \%$ of seronegative cases. This is suggestive that S.Vit.-B12 and Folic Acid deficiency was more in seropositive cases. Subclinical hypothyroidism was reported in both seronegative (5\%) and seropositive (13.33\%). Although subclinical hypothyroidism was reported more in seropositive cases than seronegative but this difference was statistically insignificant ( $P$ value $>0.05$ ). So in our study we observed that Celiac Diseases should be suspected and may be diagnosed in children suffering with Severe Acute Malnutrition on the basis of clinical features and Celiac Disease serology (tTg-IgA/IgG). By early screening and sero-diagnosis of Celiac Disease in malnourished children we can prevent further growth and development related morbidity.

Limitation of the Study- Our study was solely based on clinical features and serology for diagnosis of Celiac Disease. We were not able to do upper GI endoscopy for duodenal biopsy or HLA-DQ2/DQ8 typing for confirmation because of non-availability/feasibility at our centre.

\section{Conclusion}

Sero-positivity of Celiac Disease observed in children of 1-5 years age, suffering from Severe Acute Malnutrition was $27.28 \%$ in our study. Recurrent diarrhea was found to be common clinical features at the time of admission in sero-positive patients. In $\mathrm{tTg}-$ IgA sero-positive cases recurrent diarrhea was common clinical feature while in $\mathrm{tTg}-\mathrm{IgG}$ sero-positive cases recurrent blood in stool was common. Macrocytic anemia in peripheral blood film associated with S. Vit. B12 \& Folic acid deficiency was more common in celiac seropositive children with severe acute malnutrition.

\section{Contribution by authors}

- Pradeep Meena: Conceptualization, supervision of data collection, analysis, manuscript writing and finalizing of manuscript

- Mahendra Meena: Data analysis and Manuscript reviewing

- Namir Khan: Data Collection, drafting manuscript

- Priyanka Meena: Data Collection, drafting manuscript

\section{What this study adds to existing knowledge?}

This study enforces the existing knowledge that we should have high index of suspicion for celiac disease in children suffering from severe acute malnutrition who 
have recurrent diarrhea and anemia and should be screened and treated accordingly.

Funding: Nil, Conflict of interest: None initiated, Perission from IRB: Yes

\section{References}

1. Farrell RJ, Kelly CP. Celiac sprue. N Engl J Med. 2002 Jan 17;346(3):180-8. DOI:10.1056/ NEJMra 010852

2. Bhatnagar S, Tandon N. et al. Diagnosis of celiac disease. Indian J Pediatr. 2006 Aug;73(8):703-9.

3. Hu WT, Murray JA, Greenaway MC, et al. Cognitive impairment and celiac disease. Arch Neurol. 2006 Oct; 63(10):1440-6.

4. Cooke WT, Smith WT. Neurological disorders associated with adult Celiac Disease. Brain.1966;89 (4):683-22. https://doi.org/10.1093/brain/89.4.683

5. Marks J, Shuster S, Watson A. Small-bowel changes in dermatitis herpetiformis. The Lancet. 1966;2 (7476):1280-82. DOI: https://doi.org/10.1016/S01406736 (66)91692-8

6. Pengiran Tengah DS, Wills AJ, Holmes GK. Neurological complications of coeliac disease. Postgrad Med J. 2002 Jul; 78(921):393-8.

7. Hadjivassiliou M, Grunewald RA, Davies-Jones GA. Gluten Sensitivity as a neurological illness. J Neurol Neurosurg Psychiatry.2002;72 (5):560-63.doi: 10.1136 /jnnp.72.5.560.

8. NetoJIS, Costa AC, Magalhaes FG, Silva GS. Neurological manifestations of Celiac Disease. Arch Neuropsiquiatr.2004;62:969-72. http://dx.doi.org/10. 1590/ S0004-282X2004000600007

9. Reilly NR, Green PH. Epidemiology and clinical presentations of celiac disease. Semin Immunopathol. 2012 Jul;34(4):473-8. doi: 10.1007/ s00281-012-03112. Epub 2012 Apr 24.

10.Khoshoo V, Bhan MK, Jain R, et al. Coeliac disease as cause of protracted diarrhoea in Indian children. Lancet. 1988 Jan 16;1(8577):126-7.
11. Patwari AK, Anand VK, Kapur G, et al. Clinical and nutritional profile of children with celiac disease. Indian Pediatr. 2003 Apr;40(4):337-42.

12. García-Manzanares A, Lucendo AJ. Nutritional and dietary aspects of celiac disease. Nutr Clin Pract. 2011 Apr;26(2):163-73. doi: 10.1177/0884533611399773.

13. Caruso R, Pallone F, Stasi E, Romeo S, Monteleone G. Appropriate nutrient supplementation in Celiac Disease. Annals of Medicine.2013;45(8): 522-31. doi: 10.3109/07853890.2013.849383. Epub 2013 Nov 7

14. Kumar P, Mishra K, Singh P, Rai K. Should we screen children with severe acute malnutrition for celiac disease? Indian Pediatr. 2012;49(4):330-31.

15. Beniwal N, Ameta G, Chahar CK. Celiac Disease in children with severe acute malnutrition (SAM) a hospital-based study. Indian J Pediatr. 2017;84(5): 339-43.

16. Singh S, Shekhar C, Acharya R, et al. The incidence of abortion and unintended pregnancy in India, 2015. Lancet Glob Health. 2018 Jan;6(1):e111-e120. doi: 10. 1016/S2214-109X(17)30453-9.

17. Aesku. Diagnostics. Aeskulisa- Instruction Manual: tTG new generation (Ref 3503/3504) available atwww.aesku.com [Last accessed on Nov. 20, 2018]

18. Sharma M, Mandot S. Prevalence and clinical profile of celiac disease among malnourished children in South Rajasthan, India. Int J Contemp Pediatr. 2018;5(3):997-1002. DOI: http://dx.doi.org/ 10.18203/ 2349-3291.ijcp20181529

19. Centers for Disease Control and Prevention. Available at: www.cdc.gov/nchc/data/nhans-0304/106c-metfolates\%20B12.pdf.

20. Lerner NB. Folic Acid Deficiency. In: Kliegman RSM, Stanton BF, St. Geme III JW, editors. Nelson Textbook of Pediatrics $20^{\text {th }}$ edition, Philadelphia Elsevier, 2016: p-2319-23.

21. La Franchi SH, Huang SA. Hypothyroidism. In: Kliegman RM, Stanton BF, St. Geme III JW, editors. Nelson Textbook of Pediatrics $20^{\text {th }}$ edition. Philadelphia Elsevier, 2016: p 2665-74.

\section{How to cite this article?}

Meena P., Meena M., Khan N., Meena P. Clinico-laboratory profile of Seropositive Celiac Diseases in Severe Acute Malnutrition. Int J Pediatr Res. 2019;6(04):158-165 doi:10.17511/ijpr.2019.104.02 